\title{
EFFECT OF SPLIT APPLICATION OF NITROGEN FERTILIZER ON MORPHO-PHYSIOLOGICAL ATTRIBUTES AND GRAIN YIELD OF BROADCAST SEEDED EGYPTIAN HYBRID RICE (I) \\ Elkhoby, W. M. ${ }^{1}$; A. M. El-Khtyar'; H. M. Hassan'; B. B. Mikhael ${ }^{1}$ and Kh. A. Abdelaal ${ }^{2}$ \\ ${ }^{1}$ Rice Research and Training Center, Filed Crops Research Institute, ARC, Giza, Egypt. \\ ${ }^{2}$ Botany Department, Faculty of Agriculture, Kafr Elsheikh University, Egypt.
}

\begin{abstract}
An experiment was carried out at the Experimental Farm of Rice Research and Training Center (RRTC), Sakha, Kafr El-Sheikh, Egypt, during 2011 and 2012 seasons. The experiment was laid out in a split plot design with four replications. The main plots were devoted to the nitrogen level $220 \mathrm{~kg} \mathrm{~N} / \mathrm{ha}$ in form of urea $(46.5 \% \mathrm{~N})$. The sub-plots were allocated to the six times of nitrogen application to assess the effect of six nitrogen application treatments, viz., T_1: $(2 / 3)$ as $\mathrm{B}$ ( basal ) $+1 / 3$ at $\mathrm{PI}$ ( panicle initiation)), T 2: ( 13 as $\mathrm{B}+\sqrt{3}$ at $\mathrm{MT}$ (mid-tillering) $+\sqrt{3}$ at $\mathrm{PI}$. )), T 3:(1/2 as $\mathrm{B}+1 / 4$ at $\mathrm{MT}+1 / 4$ at $\mathrm{PI})$.$) , T_4 (1 / 4$ as $\mathrm{B}+1 / 4$ at $\mathrm{MT}+1 / 4$ at $\mathrm{PI}+1 / 4$ at BT (booting)), $\mathrm{T}$ 5: $(1 / 4$ as $\mathrm{B}+1 / 4$ at $\mathrm{MT}+\bar{V} / 4$ at $\mathrm{BT}+1 / 4$ at $\mathrm{CH}$ (complete heading)), and T 6:(1/4 as $\mathrm{B}+1 / 4$ at $\mathrm{MT}+1 / 4$ at $\mathrm{PI}+1 / 4$ at $\mathrm{F}$ ( flowering)) on morpho-physiological attributes and grain yield of Egyptian hybrid rice (1) under broadcast seeded-rice. The results revealed that nitrogen levels caused significant increases in all morphophysiological attributes and grain yield of Egyptian hybrid rice (1), except for number of primary branches/panicle, number of panicle $/ \mathrm{m}^{2}$, panicle weight and 1000 -grain weight in both seasons. Leaf area index and dry matter production at flowering were significantly increased in first and second seasons, respectively, Increasing N-level up to $220 \mathrm{~kg} \mathrm{~N} /$ ha significantly increased number of unfilled grains/panicle and straw yield t/ha. In addition, application of $165 \mathrm{~kg} \mathrm{~N} /$ ha produced the highest values of number of filled grains/panicle, grain yield t/ha and harvest index in both seasons. Moreover, It was observed that the highest estimated values of dry matter production at panicle initiation and straw yield; and the lowest number of panicles $/ \mathrm{m}^{2}$ were recorded in the first treatment $\left(T_{-} 1\right)$, without significant differences with the $\left(T_{2} \rrbracket_{-}(3)\right)$ and $\left.\llbracket\left(T_{2}\right]_{-}(5)\right)$ treatments in both seasons. The highest dry matter production at flowering, LAl at flowering, chlorophyll content in flag leaf, days to $50 \%$ heading, plant height at harvest, number of primary branches/panicle, panicle weight, heaviest 1000-grain weight, harvest index and grain yield were exhibited in $\left.\llbracket(T) \_(6)\right)$ in both seasons, The interaction between nitrogen levels and time of nitrogen application had significant effect on dry matter production $\left(\mathrm{g} / \mathrm{m}^{2}\right)$ at panicle initiation, leaf area index at both panicle initiation and at flowering, chlorophyll content in flag leaf and number of tillers $/ \mathrm{m}^{2}$, number of filled grains/panicle in both seasons and number of unfilled grains/panicle in the second season. From the obtained results, it could be recommended that splitting of $\mathrm{N}$-fertilizer application with the rate of $165 \mathrm{~kg} / \mathrm{ha}$ in four equal doses i.e. as basal application, mid-tillering, panicle initiation and at the flowering stages were played a remarkable role for achievement of high yield production from Egyptian hybrid (1) rice genotype, when it grown under broadcast seeded rice under normal soil in Egypt.
\end{abstract}


Elkhoby, W. M. et al.

Keywords: Rice; nitrogen; split application; morpho-physiological; chlorophyll and grain yield.

\section{INTRODUCTION}

Rice (Oryza sativa L.) is a very important food crop, being the primary food source for more than one third of the world's population, and grown in $11 \%$ of the world's cultivated area (Khush, 1993). Improved cultivation of Egyptian hybrid rice and judicious application of fertilizers are of the most effective means for maximizing yield. The fact is that rice plants require more nutrients to produce more yields. Yield increase $(70-80 \%)$ of field rice could be obtained by the application of nitrogen fertilizer (IFC, 1982).

Optimum dose of nitrogen fertilization plays a vital role in growth and development of rice plant. Its growth is seriously hampered when lower dose of nitrogen is applied which drastically reduces yield. Nitrogen has a positive influence on the production of effective tillers per plant, yield and yield attributes (Jashim et al. (1984) and BRRI, (1990)). Excessive nitrogen fertilization encourages vegetative growth which makes the plant susceptible to insects and diseases which ultimately reduces yield. So, it is essential to find out the optimum rate of nitrogen application for efficient utilization of this element by the plants for better yield. By applying proper dose, we can save money and can also keep our environment sound. Heavy use of fertilizer affects the soil and also the environment through the residual effect of fertilizer. Selection of the most appropriate level of nitrogen fertilization is a major concern of economic viability of crop production and the impact of agriculture .

Timing of fertilizer application may be the most critical factor in determining fertilizer uptake efficiency and crop yield. This is especially true for nitrogen fertilizer when fertilizer is applied near the time of physiological plant demand, therefore, the plant is able to efficiently uses the nutrients. The more splits of nutrients used, the less opportunity there will be for loss. So we should manage the nitrogen fertilizer schedules to best match application with the plant demands. Split application of nitrogen as compared to single application can reduce potential nitrogen losses by up to $30 \%$ and reduce potential groundwater contamination. In order to obtain the maximum effect of nitrogen fertilizer, it is not only important to resort correct dose of the fertilizer but also to apply it in appropriate time (Thakur, 1993).

Therefore, the present investigation was conducted to find out proper split application of $\mathrm{N}$ fertilizer for optimum growth, morpho-physiological attributes, grain yield and to clarify the best method and time of nitrogen application to increase the nitrogen use efficiency for hybrid rice plants under broadcast seeded-rice and seed-borne fungi, in parallel with enhancing the performance of rice in transplanted rice culture and consequently increase grain yield.

\section{MATERIALS AND METHODS}


The present investigation was conducted at the Experimental Farm of Rice Research and Training Center (RRTC), Sakha, Kafr El-Sheikh, Egypt, during 2011 and 2012 seasons to study the response of Egyptian rice hybrid 1 to proper split application of $\mathrm{N}$ fertilizer for optimum growth, morphophysiological attributes and grain yield; and to clarify the best method and time of nitrogen application to increase the nitrogen use efficiency for hybrid rice plants under broadcast seeded-rice. The preceding crop was wheat in both seasons.

The experimental soil was clayey in texture. Soil samples from the experimental sites were collected at $0-30 \mathrm{~cm}$ from the soil surface, air-dried, then ground to pass through a $2 \mathrm{~mm}$ sieve and well mixed. The fine soil samples were mechanically and chemically analyzed following the methods described by Black et al. (1965). The results of mechanical and chemical soil properties are presented in Table 1. The permanent field was plowed twice followed by wet levelling. Calcium super phosphate (15.5\% P2O5) was added on dry and untilled soil at the rate of $240 \mathrm{~kg} / \mathrm{ha}(100 \mathrm{~kg} / \mathrm{fed}$.). Zinc sulphate (28\% ZnSo4) was added after puddling and before planting at the rate of $24 \mathrm{~kg} / \mathrm{ha}$ ( $10 \mathrm{~kg} / \mathrm{fed}$. ). Potassium sulfate was added at rate of $120 \mathrm{~kg} \mathrm{~K} 2 \mathrm{O} / \mathrm{ha}$, half of this dose was applied after land leveling and the second half was added at late booting stage. Nitrogen rate was determined for each plot according to the studied treatments. Seeding rate was $24 \mathrm{~kg} / \mathrm{ha}(10 \mathrm{~kg} / \mathrm{fed}$. ). Seed was soaked in fresh water for about 48 hours then incubated twenty four hours to guarantee good germination. On May 25, seeds were manually broadcasted directly for each plot. The weeds were controlled chemically using Saturn $50 \%$ \{ S-( 4- Chlorophenol methyl) diethyl carbamothioate $\}$ at the rate of 4.8 liters/ha dissolved in 250 liters of water and sprayed nine days after sowing. Plots were kept flooded till 2-3 weeks before harvesting. All other agronomic practices were followed as recommended during the growing season.

The experiments were laid out in a split plot design with four replications. The plot area was $15 \mathrm{~m}^{2}, 3 \mathrm{~m}$ in width and $5 \mathrm{~m}$ in length. The main plots were devoted to the nitrogen level $(220 \mathrm{~kg} \mathrm{~N} / \mathrm{ha})$ in form of urea $(46.5 \% \mathrm{~N})$. The sub-plots were allocated to the six times of nitrogen application. Nitrogen application treatments were, $\mathrm{T}_{1}:\left({ }^{2} / 3\right.$ as $\mathrm{B}$ ( basal ) + $1 / 3$ at $\mathrm{PI}$ ( panicle initiation)), $\mathrm{T}_{2}:(1 / 3$ as $\mathrm{B}+1 / 3$ at $\mathrm{MT}$ (mid-tillering) $+1 / 3$ at PI.)), $\mathrm{T}_{3}:(1 / 2$ as $\mathrm{B}+1 / 4$ at $\mathrm{MT}+1 / 4$ at $\mathrm{PI}$.) $), \mathrm{T}_{4}:(1 / 4$ as $\mathrm{B}+1 / 4$ at $\mathrm{MT}$ $+1 / 4$ at $\mathrm{PI}+1 / 4$ at $\mathrm{BT}$ (booting)), $\mathrm{T}_{5}:(1 / 4$ as $\mathrm{B}+1 / 4$ at $\mathrm{MT}+1 / 4$ at $\mathrm{BT}+$ $1 / 4$ at $\mathrm{CH}$ (complete heading)), and $\mathrm{T}_{6}:(1 / 4$ as $\mathrm{B}+1 / 4$ at $\mathrm{MT}+1 / 4$ at $\mathrm{PI}$ $+1 / 4$ at $\mathrm{F}$ ( flowering)).

Data were collected and recorded on grain yield and its components at maturity stage. Chlorophyll content was measured at post flowering stage following the procedure of Arnon, (1949). Leaf samples were collected at post flowering stage and was weighed separately. In a digital scale $0.05 \mathrm{~g}$ of fresh leaves was measured separately. Samples were maturated in $80 \%$ acetone. 
These were then centrifuged for 10 minutes and finally made a volume of 5 $\mathrm{ml}$ with acetone (80\%). The optical density was measured at 645 and 663 with a spectrophotometer. Chlorophyll content (expressed as $\mathrm{mg} / \mathrm{gfw}$ of a sample) was estimated as follows:

$$
\begin{aligned}
& \text { Total chlorophyll }=(20.2 \times \mathrm{D} 645+8.02 \times \mathrm{D} 663) \times \frac{5}{1000 \times 0.05} \mathrm{mg} / \mathrm{gfw} \\
& \text { Chlorophyll } \mathrm{a}=(12.7 \times \mathrm{D} 663-2.69 \times \mathrm{D} 645) \times \frac{5}{1000 \times 0,05} \mathrm{mg} / \mathrm{gfw} \\
& \text { Chlorophyll } \mathrm{b}=(22.9 \times \mathrm{D} 645-4.68 \times \mathrm{D} 663) \times \frac{5}{1000 \times 0.05} \mathrm{mg} / \mathrm{gfw}
\end{aligned}
$$

Table 1: Mechanical and chemical analysis of the experimental soil sites in 2011 and 2012 seasons.

\begin{tabular}{|l|c|c|}
\hline \multirow{2}{*}{ Item } & \multicolumn{2}{|c|}{ Season } \\
\cline { 2 - 3 } & \multicolumn{2}{|c|}{ Mechanical analysis } \\
\hline \multicolumn{3}{|c|}{} \\
\hline Sand \% & 14.6 & 12.7 \\
\hline Silt \% & 30.5 & 31.8 \\
\hline Clay \% & 56.1 & 54.6 \\
\hline Texture & clay & clay \\
\hline Chemical analysis & 7.9 & 8.1 \\
\hline PH & 1.9 & 2.1 \\
\hline Electric conductivity (Ecds/m) & 1.5 & 1.7 \\
\hline Organic matter \% & 18.6 & 19.0 \\
\hline Total N ppm & 16.0 & 17.2 \\
\hline Available P ppm & 313 & 320 \\
\hline Available K ppm & 0.8 & 0.9 \\
\hline Available Zn ppm & 3.1 & 2.8 \\
\hline Available Fe ppm & 3.2 & 3.4 \\
\hline Available Mn ppm &
\end{tabular}

The data were analyzed following Analysis of Variance (ANOVA) technique and mean differences were adjusted by the multiple comparison test (Gomez and Gomez, 1984) using the statistical computer based program MSTAT-C v.2.1. (Russel, 1994) Means were compared by using Duncan's Multiple Range Test (1995).

\section{RESULTS AND DISCUSSION}

\section{1- Growth characters}

\section{1-1- Dry matter production $\left(\mathrm{g} / \mathrm{m}^{2}\right)$}

Data recorded on dry matter production $\left(\mathrm{g} / \mathrm{m}^{2}\right)$ of Egyptian hybrid rice (1) at panicle initiation and at flowering as affected by nitrogen level, time of nitrogen application as well as their interaction in 2011 and 2012 seasons are presented in Table (2). Regarding to the effect of nitrogen level on dry matter production $\left(\mathrm{g} / \mathrm{m}^{2}\right)$, data in Table 2 show that increasing nitrogen level from $165 \mathrm{~kg} \mathrm{~N} / \mathrm{ha}$ to $220 \mathrm{~kg} \mathrm{~N} / \mathrm{ha}$ significantly increased dry matter production from 709.34 to 757.29 and from 720.94 to 769.43 in the two seasons, respectively at panicle initiation stage and from 1857.03 to 1943.60 at flowering stage in 
the second season. These results might be due to the role of nitrogen in increasing leaf area, length of plants and tillering. These results are in accordance with those obtained by Arafat (2007), Badawi (2008), Baba et al. (2010), Gorgy (2010), Sheta (2010) and Fukushima et al. (2011).

With connection to times of nitrogen application, data in Table 2 showed that significant effects were exerted by times of nitrogen application on dry matter production $\left(\mathrm{g} / \mathrm{m}^{2}\right)$ at panicle initiation and at flowering in both seasons. The first treatment of nitrogen application $T 1(2 / 3$ as basal $+1 / 3$ at panicle initiation) produced the highest values of dry matter production at panicle initiation $\left(788.03\right.$ and $\left.801.94 \mathrm{~g} / \mathrm{m}^{2}\right)$ in 2011 and 2012 seasons, respectively, while, the lowest values of dry matter production at panicle initiation $\left(668.64\right.$ and $\left.688.04 \mathrm{~g} / \mathrm{m}^{2}\right)$ in the first and second seasons, respectively were obtained by the fifth treatment $T 5$ ( $1 / 4$ as basal $+1 / 4$ at MT $+1 / 4$ at BT $+1 / 4$ at complete heading ). On the other hand, application of nitrogen into four splits $\mathrm{T} 6(1 / 4$ as basal $+1 / 4$ at $\mathrm{MT}+1 / 4$ at $\mathrm{Pl}+1 / 4$ at flowering) gave the maximum values of dry matter production at flowering (1971.54 and $2039.65 \mathrm{~g} / \mathrm{m}^{2}$ ) in the first and second seasons respectively, While the lowest values of dry matter production at flowering $\left(1702.40\right.$ and $\left.1775.34 \mathrm{~g} / \mathrm{m}^{2}\right)$ in 2011 and 2012 seasons, respectively were produced when two-third of nitrogen as basal and one-third at panicle initiation were applied. These results are mainly attributed to the fact that nitrogen application along with the real-time paralleled with the plant nitrogen demand at various physiological growth stages especially along with first flowering encourage plant photosynthesis during plant growth through increases of all vegetative growth characters which led finally to raising dry matter production at flowering. These results are in a compatibility with Ebaid and El-Mowafi (2005) ,Arafat (2007), Sathiya and Ramesh (2009) and Nakano et al. (2011).

1-2- Leaf area index (LAl):

Results in Table 2 clarified that increasing nitrogen fertilizer level significantly increased leaf area index at panicle initiation in both study seasons. Nitrogen $f$ ertilization level significantly affected on leaf area index at flowering in 2011 season. These results may be due to the fact that nitrogen application encourages growth of leaf area as an essential element which plays a prominent role in building new merestimic cells, cell elongation and increasing photosynthesis activity of rice plants. The obtained data are in conformity with those decided by El-Rewiny et al. (2004), Pariyani and Naik (2004), Gorgy (2010) and Fukushima et al. (2011).

In relation to time of nitrogen application effect, data arranged in Table 2 indicate that times of nitrogen application had a significant effect on leaf area index at panicle initiation and flowering in both seasons. At panicle initiation, data show that the highest values of leaf area index (6.77 and 6.84) in 2011 and 2012 seasons, respectively, were obtained when the second treatment (T2) was applied ( $1 / 3$ as basal $+1 / 3$ at mid-tillering $+1 / 3$ at panicle initiation). While the lowest values of leaf area index (5.48 and 5.61) in both seasons of study, respectively, were produced when the fifth treatment T5 (1/4 as basal $+1 / 4$ at MT $+1 / 4$ at BT $+1 / 4$ at complete heading) was applied. At flowering, from Table 2, it is clear that the highest values of leaf area index ( 7.36 and 7.53 ) in the first and second seasons were produced by the sixth 
treatment ( $1 / 4$ as basal $+1 / 4$ at $M T+1 / 4$ at $\mathrm{PI}+1 / 4$ at flowering). On the other hand, the lowest values of leaf area index (6.68 and 6.77) in 2011 and 2012 seasons were obtained when the first time of nitrogen application $(2 / 3$ as basal $+1 / 3$ at panicle initiation) was applied. These results are mainly due to the fact that nitrogen splits application as various premium at physiological growth stages reply plant demand which stimulated the plant growth and raising leaf area especially along with start of flowering. These results are in agreement with that of Edwin et al. (2004), Ebaid and El-Mowafi (2005), Mohammed (2006), Arafat (2007) and El-Kallawy (2008).

Table 2: Dry matter production $(\mathrm{g} / \mathrm{m} 2)$ and Leaf area index (LAl) of Egyptian hybrid rice (1) as affected by nitrogen level, time of nitrogen application and their interaction in 2011 and 2012 seasons.

\begin{tabular}{|c|c|c|c|c|c|c|c|c|}
\hline \multirow{3}{*}{ Factor } & \multicolumn{4}{|c|}{ Dry matter production $\left(\mathrm{g} / \mathrm{m}^{2}\right)$} & \multicolumn{4}{|c|}{ Leaf area index (LAI) } \\
\hline & \multicolumn{2}{|c|}{ At panicle initiation } & \multicolumn{2}{|c|}{ At flowering } & \multicolumn{2}{|c|}{$\begin{array}{l}\text { At panicle } \\
\text { initiation }\end{array}$} & \multicolumn{2}{|c|}{ At flowering } \\
\hline & 2011 & 2012 & 2011 & 2012 & 2011 & 2012 & 2011 & 2012 \\
\hline $\begin{array}{l}\text { Nitrogen level } \\
\text { (kg N/ha) } \\
165 \\
220 \\
\text { F.test }\end{array}$ & $\begin{array}{c}709.34 \text { b } \\
757.29 a \\
\star \star\end{array}$ & $\underset{\substack{720.94 \\
769.43 \\
\star \star}}{a}$ & $\begin{array}{c}1792.63 \\
1873.74 \\
\text { N.S }\end{array}$ & $\begin{array}{c}1857.03 \mathrm{~b} \\
1943.60 \mathrm{a} \\
\star \star\end{array}$ & $\begin{array}{c}6.11 \mathrm{~b} \\
6.30 \mathrm{a} \\
\star\end{array}$ & $\begin{array}{c}6.21 \mathrm{~b} \\
6.45 \mathrm{a} \\
\star \star\end{array}$ & $\begin{array}{c}6.83 \mathrm{~b} \\
7.26 \mathrm{a} \\
\star \star\end{array}$ & $\begin{array}{l}7.03 \\
7.12 \\
\text { N.S }\end{array}$ \\
\hline $\begin{array}{l}\text { Time of N- } \\
\text { application:(T) } \\
\text { T1 } \\
\text { T2 } \\
\text { T3 } \\
\text { T4 } \\
\text { T5 } \\
\text { T6 } \\
\text { F.test } \\
\end{array}$ & $\begin{array}{c}788.03 \mathrm{a} \\
757.83 \mathrm{c} \\
767.79 \mathrm{~b} \\
718.28 \mathrm{~d} \\
668.64 \mathrm{f} \\
\underset{\star \star \star}{699.33 \mathrm{e}}\end{array}$ & $\begin{array}{c}801.94 \mathrm{a} \\
768.35 \mathrm{~b} \\
778.09 \mathrm{~b} \\
719.87 \mathrm{c} \\
688.04 \mathrm{~d} \\
\underset{\star \star}{714.81 \mathrm{c}}\end{array}$ & 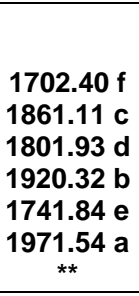 & 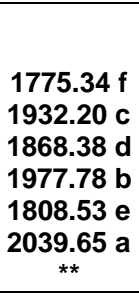 & $\begin{array}{l}6.59 \mathrm{~b} \\
6.77 \mathrm{a} \\
6.21 \mathrm{c} \\
6.10 \mathrm{~d} \\
5.48 \mathrm{e} \\
\underset{\star *}{6.09 \mathrm{~d}}\end{array}$ & $\begin{array}{l}6.70 \mathrm{~b} \\
6.84 \mathrm{a} \\
6.43 \mathrm{c} \\
6.11 \mathrm{e} \\
5.61 \mathrm{f} \\
\underset{\star \star *}{6.31 \mathrm{~d}}\end{array}$ & $\begin{array}{c}6.68 \mathrm{e} \\
7.03 \mathrm{c} \\
6.86 \mathrm{~d} \\
7.17 \mathrm{~b} \\
7.03 \mathrm{c} \\
7.36 \mathrm{a} \\
\star \star\end{array}$ & $\begin{array}{l}6.77 \mathrm{e} \\
7.15 \mathrm{~b} \\
6.98 \mathrm{~d} \\
6.97 \mathrm{~d} \\
7.07 \mathrm{c} \\
7.53 \mathrm{a} \\
\star \star\end{array}$ \\
\hline Interaction NxT & ${ }^{\star}$ & ** & N.S & N.S & ** & ** & $\star \star$ & ** \\
\hline
\end{tabular}

\section{1-3- Days to $50 \%$ heading}

As for the impact of nitrogen fertilizer level on days to heading, the results in Table 3 showed that varying nitrogen level had observable significant effect on days of $50 \%$ heading. Increasing nitrogen level delayed the heading time. The longest period from sowing to heading (87.83 and 88.50) in the first and second seasons, respectively, were produced by highest nitrogen level ( $220 \mathrm{~kg} \mathrm{~N} / \mathrm{ha}$ ). However, the low nitrogen level $(165 \mathrm{~kg}$ $\mathrm{N} / \mathrm{ha}$ ) gave the shortest period from sowing to heading (86.92 and 87.33) in 2011 and 2012 seasons, respectively. The late of heading due to high rate of $\mathrm{N}$ may be due to the increase in vegetative growth stage consequently the late in the emergence of panicle. Such results are in accordance with those found by Mikhael (2010) and Petroudi et al. (2011).

Significant differences in days to $50 \%$ heading were observed among the six tested treatments of nitrogen application. Table 3 the data indicated that applying small dose of nitrogen at beginning of heading delay the heading time by way, nitrogen splitting in four equal doses one of them at 
$50 \%$ heading was more effective in delaying heading time that might increase the dry matter production which attributed high grain yield of hybrid rice. Whereas, the longest period from sowing to heading (88.88 and 89.75) in the first and second seasons, respectively, were produced with the sixth treatment T6 (1/4 as basal $+1 / 4$ at MT $+1 / 4$ at $\mathrm{PI}+1 / 4$ at flowering). The short desirable period from sowing to heading (86.00 and 86.39) in 2011 and 2012 seasons, respectively, were obtained from the first treatment T1 (2/3 as basal $+1 / 3$ at panicle initiation) was applied. Similar findings have been found by Ebaid and El-Mowafi (2005), Mohammed (2006) and El-Kallawy (2008).

\section{1-4- Plant height at harvest $(\mathrm{cm})$}

Regardig the impact of nitrogen fertilizer level on plant height, the two tested methods of nitrogen levels had a significant effect on rice plant height in both study seasons Table 3. Increasing nitrogen level significantly increased the plant height. The tallest plants $(101.40$ and $105.32 \mathrm{~cm})$ in 2011 and 2012 seasons, respectively, were obtained when $220 \mathrm{~kg} \mathrm{~N} /$ ha was used. The desirable shortest plants $(96.26$ and $100.38 \mathrm{~cm})$ were obtained when the treatment $165 \mathrm{~kg} \mathrm{~N} / \mathrm{ha}$ were added in the first and second seasons, respectively. It is well knows that nitrogen encourages the height of rice plant through accelerating cell division and cell elongation of plants .The favorable effect of nitrogen application on plant height had been reported by El-Rewiny et al. (2004), Gewally (2006), Badawi (2008) and Gorgy (2010).

With connection to time of nitrogen application, data in Table 3 showed that significant effects were observed by time of nitrogen application on plant height at harvest in both seasons. The sixth treatment of nitrogen application (T6) surpassed the other methods of nitrogen application in this trait. The undesirable tallest plants $(104.11$ and $107.03 \mathrm{~cm}$ ) in 2011 and 2012 seasons, respectively, were produced from the sixth treatment T6( $1 / 4$ as basal $+1 / 4$ at $\mathrm{MT}+1 / 4$ at $\mathrm{PI}+1 / 4$ at flowering). While the desirable shortest plants $(94.41$ and $97.23 \mathrm{~cm}$ ) in the first and second seasons, respectively, were produced from the first treatment $\mathrm{T} 1$ ( $2 / 3$ as basal $+1 / 3$ at panicle initiation). The obtained results could be summarized as that nitrogen application is considered a suitable tactic which could continuously supply nitrogen at each growth stage according to plant demand. This means that nitrogen application at heading stage significantly increased growth characters for instance plant height. These results are in harmony with those recorded by Balasubramnian (2002), Arafat (2007), El-Kallawy (2008) and Sathiya and Ramesh (2009).

\section{1-5- Number of tillers $/ \mathrm{m}^{2}$}

It is clear from Table 3 that nitrogen level had highly significantly effects on number of tillers $/ \mathrm{m}^{2}$ in both seasons. Increasing $\mathrm{N}$-level significantly increased number of tillers $/ \mathrm{m}^{2}$ in both seasons. In the two seasons, each increment of applied nitrogen resulted in a significant increase in number of tillers $/ \mathrm{m} 2$. The highest number of tillers $/ \mathrm{m}^{2}$ (616.00 and 632.67) in the first and second seasons, respectively, were produced with $220 \mathrm{~kg}$ $\mathrm{N} / \mathrm{ha}$. The lowest numbers of tillers $/ \mathrm{m}^{2}$ (598.00 and 615.33) in 2011 and 2012 seasons, were obtained from $165 \mathrm{~kg} \mathrm{~N} / \mathrm{ha}$. Increasing tillers number due to raising $\mathrm{N}$ level might be due to the prominent role of nitrogen on vegetative growth and tillering capacity. The present findings are in agreement with 
those obtained by Salama (2005), Rahman et al. (2007) and Baba et al. (2010).

Data presented in Table 3 show that time of nitrogen application had distinct significant effect on number of tillers $/ \mathrm{m}^{2}$ in both study seasons. Both times of nitrogen application (T6\&T4) did not differ significantly in this concern. They gave the highest number of tillers $/ \mathrm{m}^{2}$ in the first and second seasons, respectively, while, the treatments (T1\&T5) produced the lowest number of tillers $/ \mathrm{m}^{2}$ in both seasons, without significant differences between them. These results could be mainly attributed to the fact that multiple nitrogen applications especially along with the beginning of flowering improved the number of tillers $/ \mathrm{m}^{2}$ by continuously abundant exit for nitrogen during all critical growth stages which the plant had edacity demand from nitrogen then finally reduce the mortality percentage at flowering and stabilize the tiller numbers $/ \mathrm{m}^{2}$. Similar results were also reported by Surekha et al. (1999), Balasubramnian (2002), Habib et al. (2002), Ebaid and El-Mowafi (2005), El-Kallawy (2008) and Sathiya and Ramesh (2009).

\section{1-6- Chlorophyll content}

The results in Table 3 , clearly showed that nitrogen fertilization significantly affected the chlorophyll content in flag leaf in 2011 and 2012 seasons. There for, increasing nitrogen fertilizer level up to $220 \mathrm{~kg} \mathrm{~N} / \mathrm{ha}$ increased chlorophyll content (\%) in flag leaf its estimated values were (39.60 and 40.15) in 2011 and 2012 seasons. On the contrary, the lowest values of chlorophyll content (38.77 and 39.27) in both seasons, respectively, were obtained when $165 \mathrm{~kg} \mathrm{~N} / \mathrm{ha}$ was used. These results might be due to the role of nitrogen as an essential element for chlorophyll formation. These findings are in line with those reported by Abd El-Salam (2003), Verma et al. (2004), Chang et al. (2008) and Sheta (2010).

Regarding to time of nitrogen application effect, data in Table 3 claimed that time of nitrogen application had a significant effect on chlorophyll content in flag leaf in 2011 and 2012 seasons. The sixth treatment of nitrogen application was found to be more effective in enhancing chlorophyll content in flag leaf over other treatments in both seasons. High values of chlorophyll content (41.39 and 41.95) were recorded in the first and second seasons, respectively, when the sixth treatment T6 (1/4 as basal $+1 / 4$ at MT $+1 / 4$ at $\mathrm{PI}+1 / 4$ at flowering) was applied. On the other hand, low values of chlorophyll content (37.23 and 37.69) in 2011 and 2012 seasons, respectively, were produced when two- third of nitrogen as basal and onethird at panicle initiation was applied. It is obviously that the application of nitrogen at complete heading stage might be had great beneficial on chlorophyll content in flag leaf through keeping the leaves green for a long time in addition to the nitrogen supply at the great role in this concern. These results are in harmony with those reported by Edwin et al. (2004) and Arafat (2007).

Table 3: Days to $50 \%$ heading, plant height $(\mathrm{cm})$, number of tillers $/ \mathrm{m}^{2}$ and Chlorophyll content of Egyptian hybrid rice (1) as affected by nitrogen level, time of nitrogen application and their interaction in 2011 and 2012 seasons. 


\begin{tabular}{|c|c|c|c|c|c|c|c|c|}
\hline \multirow{2}{*}{ Factor } & \multicolumn{2}{|c|}{$\begin{array}{l}\text { Days to } 50 \% \\
\text { heading }\end{array}$} & \multicolumn{2}{|c|}{ Plant height $(\mathrm{cm})$} & \multicolumn{2}{|c|}{$\begin{array}{c}\text { Number of } \\
\text { tillers } / \mathbf{m}^{2}\end{array}$} & \multicolumn{2}{|c|}{$\begin{array}{l}\text { Chlorophyll } \\
\text { content }\end{array}$} \\
\hline & 2011 & 2012 & 2011 & 2012 & 2011 & 2012 & 2011 & \begin{tabular}{|l|}
2012 \\
\end{tabular} \\
\hline $\begin{array}{|ll|}\text { Nitrogen } & \\
\text { level } & \text { (kg } \\
\text { N/ha) } & \\
165 & \\
220 & \\
\text { F.test } & \\
\end{array}$ & $\begin{array}{c}86.92 \mathrm{~b} \\
87.83 \mathrm{a} \\
\star \star\end{array}$ & $\begin{array}{c}87.33 \mathrm{~b} \\
88.50 \mathrm{a} \\
\star \star\end{array}$ & 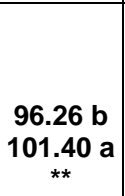 & $\underset{\star \star}{100.38} \mathbf{b}$ & $\underset{\star \star}{598.00 \mathrm{~b}} \mathbf{6 1 6 . 0 0 \mathrm { a }}$ & 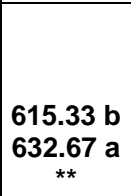 & $\begin{array}{c}38.77 \mathrm{~b} \\
39.60 \mathrm{a} \\
*\end{array}$ & $\begin{array}{c}39.27 \mathrm{~b} \\
40.15 \mathrm{a} \\
\star \star\end{array}$ \\
\hline \begin{tabular}{|l|} 
Time of $\mathrm{N}-$ \\
application:( \\
$\mathrm{T})$ \\
T1 \\
T2 \\
T3 \\
T4 \\
T5 \\
T6 \\
F.test
\end{tabular} & \begin{tabular}{|c|}
$86.00 \mathrm{~d}$ \\
$86.88 \mathrm{c}$ \\
$86.62 \mathrm{c}$ \\
$88.03 \mathrm{~b}$ \\
$87.16 \mathrm{bc}$ \\
$88.88 \mathrm{a}$ \\
$\star *$
\end{tabular} & $\mid \begin{array}{c}86.39 \mathrm{e} \\
87.63 \mathrm{~cd} \\
87.00 \mathrm{~d} \\
88.71 \mathrm{~b} \\
88.00 \mathrm{bc} \\
89.75 \mathrm{a} \\
* *\end{array}$ & $\begin{array}{c}94.41 \mathrm{~d} \\
98.58 \mathrm{c} \\
97.99 \mathrm{c} \\
101.98 \mathrm{~b} \\
96.41 \mathrm{c} \\
\underset{* *}{104.11 \mathrm{a}}\end{array}$ & $\begin{array}{c}97.23 \mathrm{~d} \\
103.69 \mathrm{~b} \\
102.73 \mathrm{~b} \\
104.18 \mathrm{~b} \\
99.94 \mathrm{c} \\
107.03 \mathrm{a} \\
* \star *\end{array}$ & $\begin{array}{l}590.00 \mathrm{c} \\
604.00 \mathrm{~b} \\
600.00 \mathrm{~b} \\
626.00 \mathrm{a} \\
590.00 \mathrm{c} \\
\underset{* *}{632.00 \mathrm{a}}\end{array}$ & $\begin{array}{l}604.00 \mathrm{c} \\
622.00 \mathrm{~b} \\
616.00 \mathrm{~b} \\
644.00 \mathrm{a} \\
608.00 \mathrm{c} \\
650.00 \mathrm{a} \\
\star * *\end{array}$ & $\begin{array}{l}37.23 \mathrm{f} \\
38.62 \mathrm{~d} \\
37.76 \mathrm{e} \\
40.83 \mathrm{~b} \\
39.27 \mathrm{c} \\
\underset{*}{41.39 \mathrm{a}}\end{array}$ & $\begin{array}{l}37.69 \mathrm{f} \\
39.04 \mathrm{~d} \\
38.27 \mathrm{e} \\
41.38 \mathrm{~b} \\
39.93 \mathrm{c} \\
41.95 \mathrm{a} \\
* *\end{array}$ \\
\hline $\begin{array}{l}\text { Interaction: } \\
\text { NxT }\end{array}$ & NS & NS & NS & NS & NS & ** & NS & * \\
\hline
\end{tabular}

\section{2- Yield and Its related characters}

\section{2-1- $\quad$ Number of panicles $/ \mathrm{m}^{2}$}

The data reported in Table 4 show that no significant differences were reported among the nitrogen levels on number of panicles $/ \mathrm{m}^{2}$ in both seasons. Concerning to the effect of time of nitrogen application on number of panicles $/ \mathrm{m}^{2}$, data in Table (4) show that the sixth treatment of nitrogen application had highly significant effect on number of panicles $/ \mathrm{m}^{2}$ in both seasons. The sixth treatment of nitrogen application T6 (1/4 as basal $+1 / 4$ at $\mathrm{MT}+1 / 4$ at $\mathrm{PI}+1 / 4$ at flowering) produced among number of panicles $/ \mathrm{m}^{2}$ in the first and second seasons, without significant differences with the fourth and second treatments of nitrogen application (T4\&T2) in both seasons. On the other hand, the first treatment of nitrogen application $T 1$ ( $2 / 3$ as basal + $1 / 3$ at panicle initiation ) produced the lowest number of panicles/m2 in 2011 and 2012 seasons, respectively, without significant differences with the third and fifth times of nitrogen application (T3\&T5) in both seasons. These results indicated that application of nitrogen consecutively according to plant $\mathrm{N}$ demand at physiological growth stages especially at the beginning of flowering significantly increased panicles $/ \mathrm{m}^{2}$ by reducing mortality percentage and stabilized panicles $/ \mathrm{m}^{2}$ at a constant during reproductive stage. The same trend was found by Stalin et al. (1999), Edwin et al. (2004), Mohammed (2006) and El-Kallawy (2008).

\section{2-2- $\quad$ Panicle length (cm)}

Results presented in Table 4 illustrate that the effect of nitrogen levels on panicle length $(\mathrm{cm})$ was significant in 2011 season. The longest panicles $(22.14 \mathrm{~cm})$ in 2011 season were found with the addition of $220 \mathrm{~kg}$ $\mathrm{N} / \mathrm{ha}$. While, the shortest panicles $(21.72 \mathrm{~cm})$ in the first season were obtained when $165 \mathrm{~kg} \mathrm{~N} / \mathrm{ha}$ was applied. This might be due to the favorable effect of nitrogen on rice plants and this in turn encouraged the growth of rice 
plants and subsequently the excersion of panicle. The present findings are in agreement with those obtained by Geethadevi et al. (2000) Abd El-Salam (2003), Islam et al. (2008), Mikhael (2010) and Sheta (2010).

Data in Table 4 revealed that panicle length $(\mathrm{cm})$ was greatly influenced by times of nitrogen application in the two study seasons. The sixth treatment T6 (1/4 as basal $+1 / 4$ at M.T $+1 / 4$ at P.I $+1 / 4$ at flowering) gave the longest panicles $(22.51 \& 22.85 \mathrm{~cm})$ in the first and second seasons, respectively, without significant differences with the fourth treatment T4 (1/4 as basal $+1 / 4$ at MT $+1 / 4$ at $\mathrm{PI}+1 / 4$ at booting). While, the shortest panicles $(21.18 \& 21.25 \mathrm{~cm})$ in the first and second seasons, respectively, were produced with the first treatment $\mathrm{T} 1$ ( $2 / 3$ as basal $+1 / 3$ at panicle initiation), application of one-fourth of nitrogen dose at the start of flowering was mainly due to the fact that the role of nitrogen at this growth stage might be speed up the formation of growth regulators such as auxines of hormones which increased the panicle exertion through increasing the internodes elongation located below the panicle. These findings are in agreement with those obtained by Balasubramnian (2002), Habib et al. (2002), Arafat (2007) and El-Kallawy (2008).

\section{2-3- Number of primary branches/ panicle}

Insignificant effects were induced by the nitrogen levels on number of primary branches/ panicle in couple of studied seasons. It was clear from Table 4 that time of nitrogen application affected significantly number of primary branches/panicle in both seasons. The sixth treatment T6 ( $1 / 4$ as basal $+1 / 4$ at MT $+1 / 4$ at $\mathrm{PI}+1 / 4$ at flowering) gave the highest number of primary branches/ panicle (10.33 \& 10.46 ) in 2011 and 2012 seasons, respectively, without significant differences with the fourth and second treatments (T4 \&T2) in both seasons. While, the first treatment $T 1$ ( $2 / 3$ as basal $+1 / 3$ at panicle initiation ) produced the lowest number of primary branches/panicle $(9.74 \& 9.79)$ in the first and second seasons, respectively , without significant differences with the third an fifth treatments (T3 \& T5) in both seasons. Similar trend was found by El-Kallawy (2008).

\section{2-4- Number of filled grains/ panicle}

Data obtained on number of filled grains/ panicle of hybrid rice as affected by nitrogen level, time of nitrogen application as well as their interaction in 2011 and 2012 seasons are listed in Table 4. Regarding the impact of nitrogen fertilizer levels on number of filled grains/ panicle, the results in Table (4) showed that varying nitrogen levels had observable significant effect on number of filled grains/ panicle in both studied seasons. In this concern, the nitrogen level $(165 \mathrm{~kg} \mathrm{~N} / \mathrm{ha})$ produced the highest number of filled grains/ panicle (135.17 \& 137.79) in the two seasons, respectively. While, nitrogen level $(220 \mathrm{~kg} \mathrm{~N} / \mathrm{ha})$ recorded the lowest number of filled grains/panicle (129.94 \& 133.00) in the first and second seasons, respectively. Nitrogen fertilization improved growth and increased the assimilate products by enhancing the source and sink consequently, resulting in more filled grains against unfilled grains/ panicle. The obtained data related to number of filled grains/ panicle completely agreed with those claimed by Meena et al. (2002), El-Rewiny et al. (2004), Salama (2005) and Mikhael (2010). 
Table 4: Number of panicles $/ \mathrm{m}^{2}$, panicle length $(\mathrm{cm})$, No. of primary branches/panicle and number of filled grains/panicle of Egyptian hybrid rice (1) as affected by nitrogen level, time of nitrogen application and their interaction in 2011 and 2012 seasons.

\begin{tabular}{|c|c|c|c|c|c|c|c|c|}
\hline \multirow[t]{2}{*}{ Factor } & \multicolumn{2}{|c|}{$\begin{array}{l}\text { Number of } \\
\text { panicles } / \mathrm{m}^{2}\end{array}$} & \multicolumn{2}{|c|}{$\begin{array}{c}\text { Panicle } \\
\text { length }(\mathbf{c m})\end{array}$} & \multicolumn{2}{|c|}{$\begin{array}{c}\text { No. of primary } \\
\text { branches/panicl } \\
\text { e }\end{array}$} & \multicolumn{2}{|c|}{$\begin{array}{l}\text { Number of filled } \\
\text { grains/panicle }\end{array}$} \\
\hline & 2011 & 2012 & 2011 & 2012 & 2011 & 2012 & 2011 & 2012 \\
\hline $\begin{array}{l}\text { Nitrogen level } \\
\text { (kg N/ha) } \\
165 \\
220 \\
\text { F.test }\end{array}$ & $\begin{array}{c}578.00 \\
590.00 \\
\text { N.S }\end{array}$ & $\begin{array}{c}593.00 \\
608.00 \\
\text { N.S }\end{array}$ & $\begin{array}{c}21.72 \mathrm{~b} \\
22.14 \mathrm{a} \\
*\end{array}$ & $\begin{array}{c}21.98 \\
22.38 \\
\text { N.S }\end{array}$ & $\begin{array}{c}10.00 \\
10.09 \\
\text { N.S }\end{array}$ & $\begin{array}{c}10.05 \\
10.20 \\
\text { N.S }\end{array}$ & $\mid \begin{array}{c}135.17 \mathrm{a} \\
129.94 \mathrm{~b} \\
\star \star\end{array}$ & $\begin{array}{c}137.79 a \\
133.00 \mathrm{~b} \\
*\end{array}$ \\
\hline $\begin{array}{l}\text { Time of N } \\
\text { application:(T) } \\
\text { T1 } \\
\text { T2 } \\
\text { T3 } \\
\text { T4 } \\
\text { T5 } \\
\text { T6 } \\
\text { F.test }\end{array}$ & \begin{tabular}{|c|}
$568.00 \mathrm{~b}$ \\
$580.00 \mathrm{ab}$ \\
$576.00 \mathrm{~b}$ \\
$602.00 \mathrm{a}$ \\
$570.00 \mathrm{~b}$ \\
$606.00 \mathrm{a}$ \\
$\star$
\end{tabular} & $\mid \begin{array}{c}584.00 \mathrm{c} \\
602.00 \mathrm{ab} \\
592.00 \mathrm{bc} \\
616.00 \mathrm{ab} \\
588.00 \mathrm{bc} \\
622.00 \mathrm{a} \\
*\end{array}$ & $\begin{array}{c}21.18 \mathrm{c} \\
21.95 \mathrm{~b} \\
21.91 \mathrm{~b} \\
22.44 \mathrm{a} \\
21.56 \mathrm{~b} \\
22.51 \mathrm{a}\end{array}$ & $\left|\begin{array}{c}21.25 \mathrm{e} \\
22.31 \mathrm{bc} \\
21.96 \mathrm{~cd} \\
22.54 \mathrm{ab} \\
21.74 \mathrm{~d} \\
22.85 \mathrm{a} \\
\star \star\end{array}\right|$ & $\begin{array}{c}9.74 b \\
10.21 a \\
9.86 b \\
10.29 a \\
9.85 b \\
10.33 a \\
\star \star\end{array}$ & $\mid \begin{array}{c}9.79 \mathrm{c} \\
10.24 \mathrm{ab} \\
9.93 \mathrm{c} \\
10.38 \mathrm{a} \\
9.88 \mathrm{c} \\
10.46 \mathrm{a} \\
\star *\end{array}$ & $\left|\begin{array}{c}122.79 \mathrm{f} \\
131.48 \mathrm{c} \\
129.81 \mathrm{~d} \\
138.36 \mathrm{~b} \\
124.76 \mathrm{e} \\
140.18 \mathrm{a} \\
\star \star\end{array}\right|$ & $\begin{array}{c}125.31 \mathrm{f} \\
134.86 \mathrm{c} \\
131.36 \mathrm{~d} \\
143.81 \mathrm{~b} \\
127.65 \mathrm{e} \\
\underset{146.54 \mathrm{a}}{\star \star}\end{array}$ \\
\hline $\begin{array}{l}\text { Interaction: } \\
\text { NxT }\end{array}$ & NS & NS & NS & NS & NS & NS & * & * \\
\hline
\end{tabular}

With respect to the influence of times of nitrogen application on number of filled grains/panicle, data are presented in Table 4 revealed that the different times of nitrogen application varied significantly regarding their effect on this character. Data confirmed the superiority of spilt of nitrogen application into four doses, one of them at flowering stage. The highest numbers of filled grains/panicle (140.18 \& 146.54 ) during the first and second seasons, respectively, were produced when one-fourth of nitrogen was applied as basal, one- fourth at MT, one-fourth at PI and one-fourth at flowering was applied. The lowest number of filled grains/panicle (122.79 \& 125.31 ) in 2011 and 2012 seasons, respectively were produced when twothird of nitrogen as basal and one-third at panicle initiation was applied. Nitrogen application at critical growth stages such maximum tillering stage, panicle initiation and heading stage for hybrid rice was effective in improving source parameter and leading to improving grain filling. Similar results were obtained by Surekha et al. (1999), Balasubramnian (2002), Edwin et al. (2004), Mohammed (2006) and Arafat (2007).

\section{2-5- Number of unfilled grains/ panicle}

As for nitrogen level effect, increasing $\mathrm{N}$-level significantly increased number of unfilled grains/panicle in both seasons Table 5 . The highest number of unfilled grains/panicle ( $5.65 \& 6.43$ ) in 2011 and 2012 seasons, respectively, were produced when $220 \mathrm{~kg} \mathrm{~N} / \mathrm{ha}$ was applied, while the lowest number of unfilled grains/panicle ( $4.03 \& 4.65)$ in the two seasons were obtained from $165 \mathrm{~kg} \mathrm{~N} / \mathrm{ha}$. The higher increases in number of unfilled grains 
of rice plants maintained at the highest level of nitrogen may be attributed to the shortage of carbohydrate supplied per grain which is directly caused by an successive number of grains produced by a heavy nitrogen fertilization. Similar trend was obtained by Salem (1997), Badawi (2002) and Salama (2005).

For the effect of times of nitrogen application on number of unfilled grains /panicle, the data listed in Table 5 show that number of unfilled grains/panicle was significantly influenced by times of nitrogen application in the two seasons. It was found that nitrogen splitting (1/4 as basal $+1 / 4$ at MT $+1 / 4$ at BT $+1 / 4$ at complete heading) significantly increased number of unfilled grains/panicle and gave the maximum number of unfilled grains/panicle ( $6.10 \& 7.08)$ in the first and the second seasons, respectively. On the other hand, the minimum number of unfilled grains/panicle (3.96 \& 4.45) in 2011 and 2012 seasons, respectively, were produced when the nitrogen splitting (1/4 as basal $+1 / 4$ at $\mathrm{MT}+1 / 4$ at $\mathrm{PI}+1 / 4$ at booting). These data are in harmony with those reported by Peng et al. (1996) and Edwin et al. (2004).

\section{2-6- Panicle weight (g)}

From Table 5, the results revealed that insignificant effects were induced by the nitrogen levels on panicle weight in both seasons. These data are in a harmony with those reported by Abd El-Salam (2003). With respect to impact of times of nitrogen application on panicle weight, it was found that panicle weight was significantly affected by times of nitrogen application in both study seasons (Table 5).

The heaviest panicles ( $3.68 \& 3.80 \mathrm{~g}$ ) in 2011 and 2012 seasons, respectively, were recorded with the sixth treatment of nitrogen application (1/4 as basal $+1 / 4$ at $M . T+1 / 4$ at $P . I+1 / 4$ at flowering) without significant differences with the fourth treatment of nitrogen application. Meanwhile, the lightest panicles $(3.00 \& 3.13 \mathrm{~g})$ in the first and second seasons, respectively, were obtained with the first treatment of nitrogen application (2/3 as basal+ $1 / 3$ at panicle initiation) was applied. It is obviously that splitting into four equal doses, one of them at flowering stage might be improved grain filling processes that might be through delaying leaf senescence and enhancing current photosynthetic rate. In addition improving store assimilates and dries matter partitioning from stem to rice grains. All previous mention reason leading to improving grain filling and resulted in heavy grain in the terms of heavy panicle weight. The present findings are in agreement with those obtained by Surekha et al. (1999), Balasubramnian (2002), Mohammed (2006), Arafat (2007) and El-Kallawy (2008).

\section{2-7- $\quad$ 1000-Grain weight (g)}

Concerning to the effect of nitrogen levels on 1000-grain weight, the results presented in Table 5 clarified that the nitrogen levels didn't exert any significant effect on 1000-grain weight in the first and second seasons of study. Data obtained during 2011 and 2012 seasons, showed that varying the times of nitrogen application resulted in significant differences in 1000-grain weight (g), as listed in Table (5). The heaviest 1000-grain weights (26.08 \& 
$26.29 \mathrm{~g}$ ) in the first and second seasons, respectively were produced with the sixth treatment $\mathrm{T} 6(1 / 4$ as basal $+1 / 4$ at $\mathrm{MT}+1 / 4$ at $\mathrm{PI}+1 / 4$ at flowering) without significant differences with the fourth, third and second treatments (T4,T3 \&T2).Whereas, the lightest 1000-grain weights $(24.87 \& 24.92 \mathrm{~g})$ in 2011 and 2012 seasons, were obtained from the first treatment T1 (2/3 as basal $+1 / 3$ at panicle initiation) was applied without significant differences with the fifth treatment T5 ( $1 / 4$ as basal $+1 / 4$ at MT $+1 / 4$ at BT $+1 / 4$ at complete heading ). Similar trend was obtained by Surekha et al. (1999), Jayakumar et al. (2004) and El-Kallawy (2008).

\section{2-8- Grain yield ( $\mathrm{t} / \mathrm{ha})$}

As a matter of fact, one of main important objectives for this study is improve grain yield with optimum and economic level of nitrogen. The results in Table 5 showed that nitrogen application had significant effect on grain yield in both seasons. The nitrogen level (165kg N/ha) was optimum one to produce the highest grain yield in both seasons. The highest values of grain yield (10.47 \& $10.62 \mathrm{t} / \mathrm{ha}$ ) in 2011 and 2012 seasons, respectively, were recorded when $165 \mathrm{~kg} \mathrm{~N} / \mathrm{ha}$ was applied. Moreover, the lowest values of grain yield (10.26 \& $10.41 \mathrm{t} / \mathrm{ha})$ in the first and second seasons, respectively were produced when the highest nitrogen level $220 \mathrm{~kg} \mathrm{~N} / \mathrm{ha}$ was used. The favorable effect of nitrogen on yield might be due to its action for improving growth as a source and sink characters and ultimately the grain yield of rice. These results are in harmony with those reported by Kumar et al. (2005), Salama (2005), Gewally (2006), Abd El-Raouf et al. (2008), Gorgy (2010), Mikhael (2010) and Fukushima et al. (2011).

With respect to the effect of nitrogen application times on grain yield, data listed in Table 5, revealed that there are significant effects for times of nitrogen application on grain yield in the two study seasons. The results indicate that more nitrogen splitting one of them added at heading stage is more favorable for increasing grain yield of hybrid rice. The maximum grain yield (10.88 \& $11.06 \mathrm{t} / \mathrm{ha})$ in the first and second seasons, respectively, were produced with the sixth treatment of nitrogen application ( $1 / 4$ as basal $+1 / 4$ at $\mathrm{MT}+1 / 4$ at $\mathrm{PI}+1 / 4$ at flowering) without significant differences with the fourth treatment of nitrogen application in the two seasons. Meanwhile, the first treatment of nitrogen application (two-third as basal + one-third at panicle initiation) gave the minimum grain yield (9.98 \& $10.05 \mathrm{t} / \mathrm{ha}$ ) in 2011 and 2012 seasons, respectively, without significant differences with the fifth treatment of nitrogen application ( $1 / 4$ as basal $+1 / 4$ at MT $+1 / 4$ at BT $+1 / 4$ at complete heading). Nitrogen application at late growth stages delayed leaf aging and increased activity of root and the three active leaves during grain filling rate and reduced the sterility percentage which greatly increased grain yield. These results are in pertinence with those reported by Peng et al. (1998), Edwin et al. (2004), JayaKumar et al. (2004), Mohammed (2006), Arafat (2007), El-Kallawy (2008) and Sathiya and Ramesh (2009).

Table 5: Number of unfilled grains/panicle, panicle weight $(\mathrm{g}), 1000$ grain weight $(\mathrm{g})$ and grain yield $(\mathrm{t} / \mathrm{ha})$ of Egyptian hybrid rice (1) as affected by nitrogen level, time of nitrogen application and their interaction in 2011 and 2012 seasons. 
Elkhoby, W. M. et al.

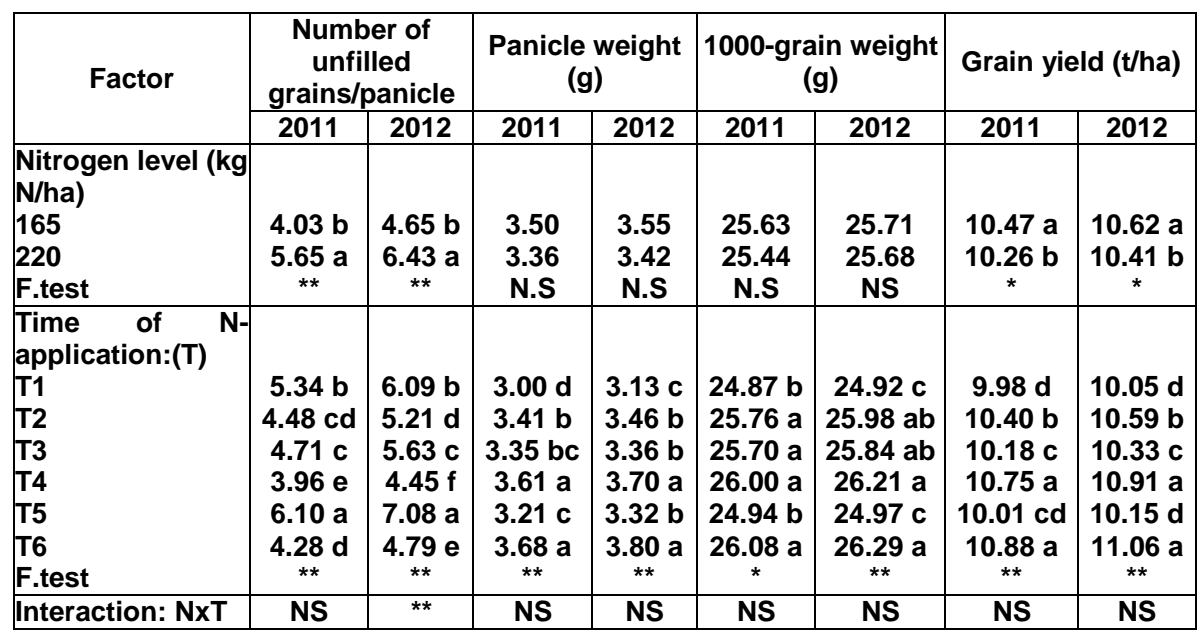

\section{3- Post harvest characters}

\section{3-1- Straw yield ( $\mathrm{t} / \mathrm{ha}$ )}

Concerning nitrogen level and its impact on straw yield, the data in Table 6 clarified that the straw yield (t/ha) significantly increased by increasing nitrogen level up to $220 \mathrm{~kg} \mathrm{~N} / \mathrm{ha}$ in both seasons. The highest values of straw yield (15.70 \& $15.81 \mathrm{t} / \mathrm{ha})$ in 2011 and 2012 seasons, respectively, were produced from application of nitrogen fertilizer at $220 \mathrm{~kg}$ $\mathrm{N} / \mathrm{ha}$. On the other hand, the lowest values of straw yield (15.06 \& $15.16 \mathrm{t} / \mathrm{ha})$ in the first and second seasons, respectively, were obtained when the lower level of nitrogen $(165 \mathrm{~kg} \mathrm{~N} / \mathrm{ha}$ ) was applied in both seasons. The nitrogen application improved growth characters such as dry matter, leaf area index, plant height and tiller formation, consequently, increase the straw yield. The obtained data are in agreement with those reported by Balasubramnian (2002), Arafat (2007), Badawi (2008), Gorgy (2010) and Mikhael (2010).

With respect to the effect of times of nitrogen application on straw yield Table 6 , the results clearly showed that times of nitrogen application had significant effect on straw yield in both seasons. The highest values of straw yield (15.52 \& $15.65 \mathrm{t} / \mathrm{ha})$ in the first and second seasons, respectively, were produced from the first treatment $\mathrm{T} 1$ ( $2 / 3$ as basal $+1 / 3$ at panicle initiation ) without significant differences with the treatments ( T2,T3\&T5) in both seasons. Meanwhile, the lowest values of straw yield (15.15 \& $15.11 \mathrm{t} / \mathrm{ha})$ in 2009 and 2010 seasons, respectively, was obtained with the sixth treatment T6 (1/4 as basal $+1 / 4$ at MT $+1 / 4$ at $\mathrm{PI}+1 / 4$ at flowering) without any significant differences with the fourth treatment T4 (1/4 as basal $+1 / 4$ at MT + $1 / 4$ at $\mathrm{PI}+1 / 4$ at booting) in the two seasons. These findings are in harmony with those reported by Balasubramnain (2002), Ebaid and El-Mowafi (2005), Arafat (2007) and El-Kallawy (2008).

\section{3-2- $\quad$ Harvest index ( $\mathrm{HI}$ )}

Respecting the effect of nitrogen fertilizer level on harvest index, the results of harvest index in Table 6 clarified that the nitrogen fertilizer level showed significant effect on harvest index in the first and second seasons. 
However, increasing nitrogen fertilizer level up to $220 \mathrm{~kg} \mathrm{~N} / \mathrm{ha}$ significantly reduced harvest index. The highest values of harvest index (41.00 \& 41.22) in the first and second seasons, respectively, were produced when $165 \mathrm{~kg} \mathrm{~N} / \mathrm{ha}$ was used. While, the lowest values of harvest index (39.52 \& 39.69) in 2011 and 2012 seasons, respectively, were obtained when $220 \mathrm{~kg} \mathrm{~N} / \mathrm{ha}$ was applied. The reduction of harvest index value with high nitrogen fertilizer level could be mainly due to the reduction in grain yield. These results are in accordance with those of Arafat (2007), Rahman et al. (2007), Baba et al. (2010), Mikhael (2010) and Sheta (2010).

Table 6: Straw yield ( $t / h a)$ and harvest index of Egyptian hybrid rice (1) as affected by nitrogen level, time of nitrogen application and their interaction in 2011 and 2012 seasons.

\begin{tabular}{|c|c|c|c|c|}
\hline \multirow{2}{*}{ Factor } & \multicolumn{2}{|c|}{ Straw yield (t/ha) } & \multicolumn{2}{|c|}{ Harvest index } \\
\hline & 2011 & 2012 & 2011 & 2012 \\
\hline \begin{tabular}{|lll} 
Nitrogen & level $\quad$ (kg \\
N/ha) & & \\
165 & & \\
220 & & \\
F.test & & \\
\end{tabular} & $\begin{array}{l}15.06 \mathrm{~b} \\
15.70 \mathrm{a} \\
\star \star\end{array}$ & $\begin{array}{c}15.16 \mathrm{~b} \\
\underset{\star \star}{15.81} \mathrm{a}\end{array}$ & $\begin{array}{c}41.00 \mathrm{a} \\
39.52 \mathrm{~b} \\
\star \star\end{array}$ & $\begin{array}{c}41.22 \mathrm{a} \\
39.69 \mathrm{~b} \\
\star \star *\end{array}$ \\
\hline $\begin{array}{l}\text { Time of } \\
\text { application:(T) } \\
\text { T1 } \\
\text { T2 } \\
\text { T3 } \\
\text { T4 } \\
\text { T5 } \\
\text { T6 } \\
\text { F.test } \\
\end{array}$ & $\begin{array}{c}15.52 \mathrm{a} \\
15.48 \mathrm{a} \\
15.49 \mathrm{a} \\
15.19 \mathrm{~b} \\
15.46 \mathrm{a} \\
15.15 \mathrm{~b} \\
\text { * }\end{array}$ & $\begin{array}{c}15.65 \mathrm{a} \\
15.59 \mathrm{ab} \\
15.57 \mathrm{ab} \\
15.33 \mathrm{bc} \\
15.56 \mathrm{ab} \\
15.11 \mathrm{c} \\
{ }^{* *}\end{array}$ & $\begin{array}{l}39.15 \mathrm{c} \\
40.19 \mathrm{~b} \\
39.66 \mathrm{c} \\
41.44 \mathrm{a} \\
39.30 \mathrm{c} \\
41.80 \mathrm{a} \\
{ }_{\star \star}\end{array}$ & $\begin{array}{c}39.08 \mathrm{e} \\
40.52 \mathrm{c} \\
39.87 \mathrm{~d} \\
41.55 \mathrm{~b} \\
39.51 \mathrm{~d} \\
\underset{* *}{42.25 \mathrm{a}} \\
\end{array}$ \\
\hline Interaction: NxT & NS & NS & NS & NS \\
\hline
\end{tabular}

According to the analysis of variance, data show that there were significant differences among the six treatments of nitrogen application regarding the harvest index in both seasons, Table 6 . The highest values of harvest index (41.80 \& 42.25) in the first and second seasons, respectively, was produced by T6 without significant difference with T4 in the first season. While, the lowest values of harvest index (39.15 \& 39.08) in 2011 and 2012 seasons, respectively, were produced by using $\mathrm{T} 1$ without significant differences with T3\& T5 in 2009 season. These results might be due to the magic effect of the last premium dose of nitrogen applied at flowering which take its effectiveness in physiological and nutrimental improvement of rice plants which resulted in dimension of grain yield and ultimate increased harvest index. Similar trend was obtained by Stalin et al. (1999), Habib et al. (2002), Edwin et al. (2004), Mohammed (2006), Arafat (2007) and El-Kallawy (2008)

4- The interaction between nitrogen level and time of nitrogen application for some studied characters in 2011 and 2012 seasons

4-1- Dry matter production $\left(\mathrm{g} / \mathrm{m}^{2}\right)$ at panicle initiation and number of filled grains/panicle characters 
The interaction between nitrogen level and time of nitrogen application significantly affected dry matter production at panicle initiation in both seasons, Table 7 . The highest values of dry matter production (815.13 and $824.16 \mathrm{~g} / \mathrm{m} 2$ ) in 2011 and 2012 seasons, respectively, were obtained by the first treatment $T 1$ ( $2 / 3$ as basal $+1 / 3$ at panicle initiation ) and highest nitrogen fertilizer level of $220 \mathrm{~kg} \mathrm{~N} / \mathrm{ha}$. The lowest values of dry matter production $(648.60$ and $661.48 \mathrm{~g} / \mathrm{m} 2)$ in both seasons were produced when the fifth treatment T5( $1 / 4$ as basal $+1 / 4$ at MT $+1 / 4$ at BT $+1 / 4$ at complete heading ) and lowest nitrogen fertilizer level of $165 \mathrm{~kg} \mathrm{~N} / \mathrm{ha}$ were applied.

Table 7: Effect of the interaction between nitrogen level and time of nitrogen application on dry matter production $(\mathrm{g} / \mathrm{m} 2)$ at panicle initiation and number of filled grains/panicle in 2011 and 2012 seasons.

\begin{tabular}{|c|c|c|c|c|c|c|c|c|}
\hline \multirow{4}{*}{ 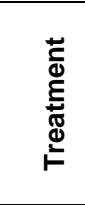 } & \multicolumn{4}{|c|}{$\begin{array}{l}\text { Dry matter production }\left(\mathrm{g} / \mathrm{m}^{2}\right) \text { at panicle } \\
\text { initiation }\end{array}$} & \multicolumn{4}{|c|}{ number of filled grains/panicle } \\
\hline & \multicolumn{2}{|c|}{2011 season } & \multicolumn{2}{|c|}{2012 season } & $\begin{array}{c}2011 \\
\text { season }\end{array}$ & \multicolumn{3}{|c|}{2012 season } \\
\hline & \multicolumn{4}{|c|}{ Nitrogen level (kg N/ha } & \multicolumn{4}{|c|}{ Nitrogen level (kg N/ha } \\
\hline & 165 & 220 & 165 & 220 & 165 & 220 & 165 & 220 \\
\hline$T_{1}$ & $760.93 \mathrm{~d}$ & $815.13 \mathrm{a}$ & $779.72 \mathrm{c}$ & $824.16 a$ & $124.90 \mathrm{~g}$ & $124.58 \mathrm{~g}$ & $126.45 \mathrm{f}$ & $126.55 \mathrm{f}$ \\
\hline$T_{2}$ & $733.00 \mathrm{f}$ & $782.66 \mathrm{c}$ & $738.85 \mathrm{de}$ & 797.86 b & $133.53 \mathrm{~d}$ & $129.43 \mathrm{e}$ & $137.25 \mathrm{c}$ & $132.69 \mathrm{~d}$ \\
\hline $\mathrm{T}_{3}$ & $741.51 \mathrm{e}$ & 794.08 b & $752.71 \mathrm{~d}$ & $803.48 \mathrm{~b}$ & $131.78 \mathrm{~d}$ & 127.85 ef & $130.38 \mathrm{de}$ & $132.35 \mathrm{~d}$ \\
\hline$T_{4}$ & $696.78 \mathrm{~h}$ & $739.77 \mathrm{e}$ & $708.18 \mathrm{f}$ & $731.55 \mathrm{e}$ & $139.45 \mathrm{~b}$ & $137.28 \mathrm{c}$ & $143.70 \mathrm{~b}$ & $143.93 \mathrm{~b}$ \\
\hline$T_{5}$ & $648.60 \mathrm{k}$ & $688.69 \mathrm{i}$ & $661.48 \mathrm{~h}$ & $714.60 \mathrm{f}$ & $126.30 \mathrm{fg}$ & $120.23 \mathrm{~h}$ & 128.75 ef & $122.78 \mathrm{~g}$ \\
\hline$T_{6}$ & $675.25 \mathrm{j}$ & $723.41 \mathrm{~g}$ & $684.70 \mathrm{~g}$ & $744.93 \mathrm{de}$ & $143.05 \mathrm{a}$ & $137.30 \mathrm{c}$ & $148.20 \mathrm{a}$ & $144.88 \mathrm{~b}$ \\
\hline
\end{tabular}

On the other hand, the maximum number of filled grains/panicle (143.05 \& 148.20) in the first and second seasons, respectively, were recorded under the sixth treatment T6 (1/4 as basal $+1 / 4$ at MT $+1 / 4$ at PI + $1 / 4$ at flowering) and applied $165 \mathrm{~kg} \mathrm{~N} / \mathrm{ha}$. Moreover, the minimum number of filled grains/ panicle (120.23\& 122.78) in 2011 and 2012 seasons, respectively, were produced from the fifth treatment T5 $(1 / 4$ as basal $+1 / 4$ at MT+ $1 / 4$ at BT + 1/4 at complete heading) which fertilized by $220 \mathrm{~kg} \mathrm{~N} / \mathrm{ha}$.

4-2- leaf area index (LAl) at panicle initiation and leaf area index (LAl) at flowering characters

The interaction among nitrogen level and time of nitrogen application had significant effect on leaf area index (LAI) at panicle initiation and flowering in 2011 and 2012 as showed in Table 8. the highest values of LAI at panicle initiation (6.85 and 6.93) in 2011 and 2012 seasons, respectively, were obtained by the second treatment T2 $(1 / 3$ as basal $+1 / 3$ at mid-tillering $+1 / 3$ at panicle initiation) and highest nitrogen level ( $220 \mathrm{~kg} \mathrm{~N} / \mathrm{ha}$ ), while the lowest values of LAI (5.34 and 5.53) in the first and second seasons were produced from the fifth treatment T5 (1/4 as basal $+1 / 4$ at MT $+1 / 4$ at BT $+1 / 4$ at complete heading) when nitrogen fertilizer was applied at the rate of $165 \mathrm{~kg} \mathrm{~N} / \mathrm{ha}$. On the other hand, the highest values of LAl at flowering (7.59 and 7.67) in both seasons, respectively, was obtained when the sixth 
treatment $\mathrm{T} 6(1 / 4$ as basal $+1 / 4$ at $\mathrm{MT}+1 / 4$ at $\mathrm{PI}+1 / 4$ at flowering) was applied with highest nitrogen fertilizer level ( $220 \mathrm{~kg} \mathrm{~N} / \mathrm{ha}$ ). Whereas, the lowest values of LAI (6.58 and 6.35) in 2011 and 2012 seasons were produced from the third time of nitrogen application T3 (1/2 as basal +1/4 at MT $+1 / 4$ at panicle initiation) when the lowest nitrogen fertilizer level $(165 \mathrm{~kg}$ $\mathrm{N} / \mathrm{ha}$ ) was added.

Table8: Effect of the interaction between nitrogen level and time of nitrogen application on leaf area index (LAI) at panicle initiation and leaf area index (LAI) at flowering in 2011 and 2012 seasons.

\begin{tabular}{|c|c|c|c|c|c|c|c|c|}
\hline \multirow{4}{*}{ Treatment } & \multicolumn{4}{|c|}{$\begin{array}{c}\text { leaf area index (LAI) at panicle } \\
\text { initiation }\end{array}$} & \multicolumn{4}{|c|}{ leaf area index (LAl) at flowering } \\
\hline & 2011 & ason & 2012 & ason & 2011 & ason & 2012 & eason \\
\hline & \multicolumn{4}{|c|}{ Nitrogen level (kg N/ha) } & \multicolumn{4}{|c|}{ Nitrogen level (kg N/ha) } \\
\hline & 165 & 220 & 165 & 220 & 165 & 220 & 165 & 220 \\
\hline T1 & $6.46 \mathrm{c}$ & $6.71 \mathrm{~b}$ & $6.57 \mathrm{~d}$ & 220 & $6.70 \mathrm{i}$ & $6.97 \mathrm{f}$ & $6.80 \mathrm{f}$ & $7.06 \mathrm{e}$ \\
\hline T2 & $6.68 \mathrm{~b}$ & $6.85 \mathrm{a}$ & $6.74 \mathrm{c}$ & $6.82 \mathrm{~b}$ & $6.85 \mathrm{gh}$ & $7.21 \mathrm{~cd}$ & $7.02 \mathrm{e}$ & $7.27 \mathrm{c}$ \\
\hline T3 & 6.14 ef & $6.27 \mathrm{~d}$ & $6.31 \mathrm{f}$ & $6.93 \mathrm{a}$ & $6.58 \mathrm{j}$ & $7.08 \mathrm{e}$ & $6.35 \mathrm{~h}$ & $7.16 \mathrm{~d}$ \\
\hline T44 & $6.07 \mathrm{fg}$ & 6.13 ef & $5.92 \mathrm{~h}$ & $6.55 \mathrm{~d}$ & $6.90 \mathrm{fg}$ & $7.44 \mathrm{~b}$ & $7.18 \mathrm{~d}$ & $6.89 \mathrm{~g}$ \\
\hline T5 & $5.34 \mathrm{i}$ & $5.62 \mathrm{~h}$ & $5.53 \mathrm{j}$ & $6.29 \mathrm{f}$ & $6.78 \mathrm{hi}$ & $7.27 \mathrm{c}$ & $6.93 \mathrm{f}$ & $7.20 \mathrm{~d}$ \\
\hline T6 & $5.98 \mathrm{~g}$ & $6.20 \mathrm{de}$ & $6.19 \mathrm{~g}$ & $5.68 \mathrm{i}$ & $7.12 \mathrm{de}$ & 7.59 a & $7.38 \mathrm{~b}$ & $7.67 \mathrm{a}$ \\
\hline
\end{tabular}

4-3- number of filled grains/panicle in 2011 and 2012 seasons and chlorophyll content, number of tillers $/ \mathrm{m}^{2}$ and number of unfilled grains/panicle in the second season

Data in Table 9, revealed that the maximum numbers of filled grains/panicle (143.05 \& 148.20) in the first and second seasons, respectively were recorded under the sixth treatment T6 (1/4 as basal + 1/4 at MT + 1/4 at $\mathrm{PI}+1 / 4$ at flowering ) and applied $165 \mathrm{~kg} \mathrm{~N} / \mathrm{ha}$. On the other hand, the minimum number of filled grains/ panicle (120.23\& 122.78) in 2011 and 2012 seasons, respectively were produced from the fifth treatment T5 ( $1 / 4$ as basal $+1 / 4$ at MT $+1 / 4$ at BT $+1 / 4$ at complete heading ) which fertilized by $220 \mathrm{~kg} \mathrm{~N} / \mathrm{ha}$. However, the highest value of chlorophyll content (\%) (42.43) during the second season was recorded by the sixth treatment T6 (1/4 as basal $+1 / 4$ at MT $+1 / 4$ at PI $+1 / 4$ at flowering) and fertilized by $220 \mathrm{~kg} \mathrm{~N} / \mathrm{ha}$ .The lowest value of chlorophyll content (37.49) during the second season was produced when the first time of nitrogen application $(2 / 3$ as basal $+1 / 3$ at panicle initiation) was used under $165 \mathrm{~kg} \mathrm{~N} /$ ha level of nitrogen fertilization. In addition, more number of tillers $/ \mathrm{m}^{2}$ (668.00) in 2011 season was obtained by the highest nitrogen fertilizer level $(220 \mathrm{~kg} \mathrm{~N} / \mathrm{ha})$ and the sixth treatment $\mathrm{T} 6$ (1/4 as basal $+1 / 4$ at MT+1/4 at PI + 1/4 at flowering). The lowest number of tillers $/ \mathrm{m}^{2}(592)$ in the second season was produced with the first treatment T1 $(2 / 3$ as basal $+1 / 3$ at panicle initiation) and $165 \mathrm{~kg} \mathrm{~N} / \mathrm{ha}$ of nitrogen fertilization. Moreover, data presented in Table (9) show clearly that the highest number of unfilled grains/panicle (8.30) in 2011 season was produced from the fifth treatment T5 (1/4 as basal $+1 / 4$ at MT $+1 / 4$ at BT $+1 / 4$ at complete heading ) and fertilized with $220 \mathrm{~kg} \mathrm{~N} / \mathrm{ha}$. Meanwhile, the lowest number of unfilled grains/panicle (3.80) in the second season were produced 
when the sixth treatment of nitrogen application (1/4 as basal $+1 / 4$ at MT $+1 / 4$ at $\mathrm{PI}+1 / 4$ at flowering) was applied and fertilized with $165 \mathrm{~kg} \mathrm{~N} / \mathrm{ha}$.

Table 9: Effect of the interaction between nitrogen level and time of nitrogen application on number of filled grains/panicle in 2011 and 2012 seasons and chlorophyll content, number of tillers $/ \mathrm{m}^{2}$ and number of unfilled grains/panicle in the second season

\begin{tabular}{|c|c|c|c|c|c|c|c|c|c|c|}
\hline \multirow{4}{*}{ 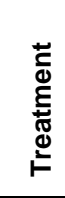 } & \multicolumn{4}{|c|}{ number of filled grains/panicle } & \multicolumn{2}{|c|}{$\begin{array}{l}\text { chlorophyll } \\
\text { content } \\
\text { in flag leaf }\end{array}$} & \multicolumn{2}{|c|}{$\begin{array}{l}\text { Number of } \\
\text { tillers } / \mathrm{m}^{2}\end{array}$} & \multicolumn{2}{|c|}{$\begin{array}{c}\text { number of } \\
\text { unfilled } \\
\text { grains/panicle }\end{array}$} \\
\hline & \multicolumn{4}{|c|}{2011 season } & \multicolumn{6}{|c|}{2012 season } \\
\hline & \multicolumn{10}{|c|}{ Nitrogen level (kg N/ha) } \\
\hline & 165 & 220 & 165 & 220 & 165 & 220 & 165 & 220 & 165 & 220 \\
\hline $\mathbf{T}_{1}$ & $124.90 \mathrm{~g}$ & $124.58 \mathrm{~g}$ & $126.45 \mathrm{f}$ & $126.55 \mathrm{f}$ & $37.49 \mathrm{~h}$ & $37.90 \mathrm{~g}$ & $592.00 \mathrm{~h}$ & 616.00 ef & $5.15 f$ & $7.03 \mathrm{~b}$ \\
\hline$T_{2}$ & $133.53 \mathrm{~d}$ & $129.43 \mathrm{e}$ & $137.25 \mathrm{c}$ & $132.69 \mathrm{~d}$ & $38.56 \mathrm{f}$ & 39.52 e & 616.00 ef & $628.00 \mathrm{~d}$ & $4.25 \mathrm{hi}$ & $6.18 \mathrm{~cd}$ \\
\hline$T_{3}$ & $131.78 \mathrm{~d}$ & 127.85 ef & $130.38 \mathrm{de}$ & $132.35 \mathrm{~d}$ & $37.95 \mathrm{~g}$ & $38.59 \mathrm{f}$ & $608.00 \mathrm{fg}$ & $624.00 \mathrm{de}$ & $4.65 \mathrm{gh}$ & $6.60 \mathrm{c}$ \\
\hline$T_{4}$ & $139.45 b$ & $137.28 \mathrm{c}$ & $143.70 \mathrm{~b}$ & $143.93 \mathrm{~b}$ & $40.86 \mathrm{~d}$ & $41.90 \mathrm{~b}$ & $640.00 \mathrm{bc}$ & $648.00 \mathrm{~d}$ & $4.08 \mathrm{i}$ & $4.83 \mathrm{fg}$ \\
\hline $\mathbf{T}_{5}$ & $126.30 \mathrm{fg}$ & $120.23 \mathrm{~h}$ & 128.75 ef & $122.78 \mathrm{~g}$ & $39.32 \mathrm{e}$ & $40.55 d$ & $604.00 \mathrm{~g}$ & $612.00 \mathrm{fg}$ & $5.85 \mathrm{de}$ & $8.30 \mathrm{a}$ \\
\hline $\mathrm{T}_{6}$ & $143.05 \mathrm{a}$ & $137.30 \mathrm{c}$ & $148.20 \mathrm{a}$ & $144.88 \mathrm{~b}$ & $41.47 \mathrm{c}$ & $42.43 \mathrm{a}$ & $632.00 \mathrm{~cd}$ & $668.00 \mathrm{a}$ & $3.80 \mathrm{j}$ & $5.68 \mathrm{e}$ \\
\hline
\end{tabular}

\section{REFERENCES}

Abd El-Raouf, M.S., E.M.A. El-Metwally, S.A. Ghanem and R.M. Abd ElSalam. 2008. Effect of hill spacings and nitrogen levels on yield and its components of two rice cultivars. Moshthor Annulas Agric. Sci., 46 (1): 53-62.

Abd El-Salam, R.M. 2003. Effect of some cultural treatment on rice yield and its components. M.Sc. Thesis, Fac of Agric., Cairo Univ., Egypt.

Arafat, E. 2007. Effect of some agronomic practices on hybrid rice. M.Sc. Thesis, Agron. Dept., Fac. Agric., Kafr El-Sheikh Univ., Egypt.

Arnon, D.I. 1949. Copper enzymes in isolated chloroplasts. Polyphenol oxidase in Beta vulgaris. Plant Physiol. 24 (1), 1-15.

Baba, M.H., S.S. Hussain, M.A. Wani and F.A. Misgar. 2010. Response of rice ( Oryza sativa, L.) to levels of nitrogen and bio-fertilizers. Res. J. of Agric. Sci., 1 (3): 237-241.

Badawi, Shimaa A.B. 2008. Effect of some cultural practices on the productivity of hybrid rice. Ph.D. Thesis, Agron. Dept., Fac. of Agric., Kafr El-Sheikh Univ., Egypt.

Balasubramnian, R. 2002. Response of hybrid rice (Oryza sativa, L.) to level and time of application of nitrogen. Indian J. of Agron., 47 (2): 203-206.

Black, C.A., D.D. Evan, L.E. Ensinger, J.L. White and F.E. Clark. 1965. Methods of soil analysis (chemical and microbiology properties, part 2). Amer. Soc. Of Agron. Inc., Publisher Madison, Wisconsin, USA 1965.

BRRI, (Bangladesh Rice Research Institute). 1990. Nitrogen response of promising variety. Annual Rep. Bangladesh Rice Res. Inst., Joydebpur, Gazipur. P: 95. 
Chang, J., C. Cougui, C. Mingli, Y. Baazhong and Z. Jing. 2008. Effect of different nitrogen nutrition and soil water potential on physiological parameters and yield of hybrid rice. Plant Nutrition and Fertilizer Sci., 14 (2): 199-206.

Duncan, D.B. (1955). Multiple range and multiple F test. Biometrics, 11:1-42.

Ebaid, R. and H. El-Mowafi. 2005. Effect of split applied nitrogen on the productivity of two rice hybrids and Sakha 104 rice cultivar. J. Agric. Res., Tanta Univ., 31 (4): 760-776.

Edwin, L., J. Krishnarajan and M. Premsekhar. 2004. Irrigation and nitrogen application schedules for hybrid "ADTRH 1" rice ( Oryza sativa, L.) in Tamil Nadu. Indian J. of Agron., 49 (11): 37-39.

El-Kallawy, W. 2008. Effect of methods and time of application of different nitrogenous sources on the productivity of hybrid rice. Ph.D. Thesis, Agron. Dept., Fac. of Agric., Kafr El-Sheikh. Univ., Egypt.

El-Rewainy, I.M., S.A. Ghanem and T.F. Metwally. 2004. Response of number rice seedling per hill to nitrogen fertilization. The International Conf. on Advanced Rice Res., Alex., Egypt, 21-23 September.

Fukushima, A., H. Shiratsuchi, H. Yamaguchi and A. Fukuda. 2011. Effect of nitrogen application and planting density on morphological traits, dry matter production and yield of large grain type rice variety Bekoaba and strategies for super high-yielding rice in the Tohoku Region of Japan. Plant Prod. Sci., 14 (1): 56-63.

Geethadevi, T., G. Andain, M. Krishnappa and R. Babu. 2000. Effect of nitrogen and spacing on growth and yield of hybrid rice. Current Res. Univ., of Agric. Sci., Bangalore, 29 (5/6): 73-75.

Gewally, E.E.A. 2006. Behavior of some nutrient in rice soils under different irrigation intervals. Ph.D. Thesis, Fac. of Agric., Mansoura Univ., Egypt.

Gomez, K. and A. Gomez. 1984. Statistical Procedures of Agricultural Research. John Wiley and Sons. Inc., New York, U.S.A.

Gorgy, R.N. 2010. Effect of transplanting spacings and nitrogen levels on growth, yield and nitrogen use efficiency of some promising rice varieties . J. Agric. Res. Kafr El-Sheikh Univ., 36 (2) 123-146.

Habib, M.A., M.A.R. Sarker, M. Rivddin, M.R. Karim and M.A. Hossain 2002. Performance of late transplant Aman rice as affected by Rate and Time of Nitrogen application. J. of Biological Sci., 2 (10): 666-668.

IFC, (International Fertilizer Correspondent). 1982. FAO/FAIC working party on the economics of fertilizer use. 23 (1), 7-10.

Islam, M.S., M.A. Hossain, M.A.H. Chowdhury and M.A. Hanan. 2008. Effect of nitrogen and transplanting date on yield and yield components of aromatic rice. J. Bangladesh Agric. Univ., 6 (2): 291-296.

Jashim, C., U. Ahmed and K.U. Ahmed. 1984. Response of rice varieties to applied N in saline soils. Int. Rice Res. Newsl., 9 (5), 22.

Jayakumar, M., S. Krishnasamy and N. Thavaprakash. 2004. Effect of irrigation regimes, mid-season drainage and time of application of nitrogen on growth and yield of hybrid rice. Acta Agronomica Hungarica, 52 1): 45-51.

Khush, G.S. 1993. Breeding rice for sustainable agricultural systems. In: D.R. Buxton, ed., International Crop Science I. Proc. Int. Crop Sci. Congr. 
Amer. IA, Crop Sci. Soc. Amer. 14-22 July, 1992. Madison, USA. p. 89199.

Kumar, R., R. Kumar, N. Shivani and K. Sanjeev. 2005. Effect of nitrogen and potassium levels on growth and yield of hybrid rice. J. of Applied Biology, 15 (1): 31-34.

Meena, S.L. S. Singh and Y. Shivay. 2002. In response of hybrid rice ( Oryza sativa, L.) to nitrogen and potassium application. Indian J. of Agron., Vol. 47 (2): 207-211.

Mikhael, B. 2010. Fertilizer requirements for hybrid rice. Ph.D. Thesis, Agron. Dept., Fac. of Agric., Kafr El-Sheikh. Univ., Egypt.

Mohammed, M. 2006. Effect of some agricultural treatments on yield of hybrid rice. M.Sc. Thesis, Agron. Dept., Fac. Agric., Al- Azhar Univ., Egypt.

Nakano, H., H. Ikuo, K. Sato and S. Morita. 2011. Early planting and early nitrogen application increase stem total digestible nutrient concentration and yield of forage rice in South western Japan. Plant Prod. Sci., 14 (2): 169-176.

Pariyani, A. and K. Naik. 2004. Effect of nitrogen level and seedling number on yield attributes and yield of rice hybrid. J. of Soils and Crops, 14 (2): 234-234.

Peng, S., F.V. Garica, R.C. Laza, A.L. Sanico, R.M. Visperas and K.G. Cassman. 1996. Increased N-use efficiency using chlorophyll mater on high yielding irrigated rice. Field Crop Res., 47: 243-251.

Peng, S., J. Yang, F.V. Carcia, R.C. Laza, R.M. Visperas, A.L. Sanico, A.Q. Chover and S.S. Virmani. 1998. Physiological-based crop management for yield maximization of hybrid rice. In : Virmani S.S, Siddiq.E.A., Muralidharan K., editors. Advances in hybrid rice technology. Proceeding of the Third International Symposium on Hybrid Rice, 14-16 November 1996. Hyderabed, India. Loss Banos, (Philippines) IRRI, P: 157-176.

Petroudi, R.E., G. Noormohammadi, M.J. Mirhadi, H. Madani, H.R. Mobasser. 2011. Effect of nitrogen fertilization and rice harvest height on agromic yield indices of ratoon rice-berseem clover intercropping system. Australian J. of Crop Sci., 5 (5): 566-574.

Rahman, M., M. Ali and M. Khatun. 2007. Effect of different levels of nitrogen on growth and yield of transplant aman rice Cv BRRI dhan32. International J. of Sustainable Crop Production, 2 (1): 28-34.

Russell, O.F. 1994. MSTAT-C (a computer based data analysis software). Crop and Soil Sci. Depart., Michigan State Univ., USA.

Salama, A.A.S. 2005. Effect of some cultural practices on rice crop. M.Sc. Thesis, Fac. of Agric., Kafr El-Sheikh, Tanta Univ., Egypt.

Salem, A.K.M. 1997. Response of some rice cultivars for Zinc under delight levels of nitrogen fertilization. M.Sc. Thesis, Fac. of Agric., Kafr ElSheikh, Tanta Univ., Egypt.

Sathiya, K. and T. Ramesh. 2009. Effect of split application of nitrogen on growth and yield of aerobic rice. Asian J. EXP. Sci., Vol. 23 (1): 303306. 
Sheta, I.A.A., (2010). Effect of planting methods and nitrogen levels on the productivity of some hybrids and inbred rice cultivars. M.Sc. Thesis, Agron. Dept., Fac. Agric., Kafr El-Sheikh Univ., Egypt.

Stalin, P., T.M. Thiyagarajan and R. Rangarajan. 1999. Nitrogen application strategy use efficiency in rice. Oryza, 36 (4): 322-326.

Surekha, K., M.N. Reddy and R.T.M. Kumar. 1999. Yields attributes and yield of rice ( Oryza sativa, L. ) hybrids as influenced by nitrogen sources and its splits application. India J. of Agron., 44 (1): 88-90.

Thakur, R.B. 1993. Performance of summer rice (Oryza sativa, L.) to varying levels of nitrogen. Indian J. of Agron., 38 (2): 187-190.

Verma, K., N. Pandey and S. Tripathi. 2004. Leaf growth, chlorophyll, nitrogen content and grain yield of hybrid rice as influenced by planting times and N levels. Annals of Agric. Res., 25(3): 456-458.

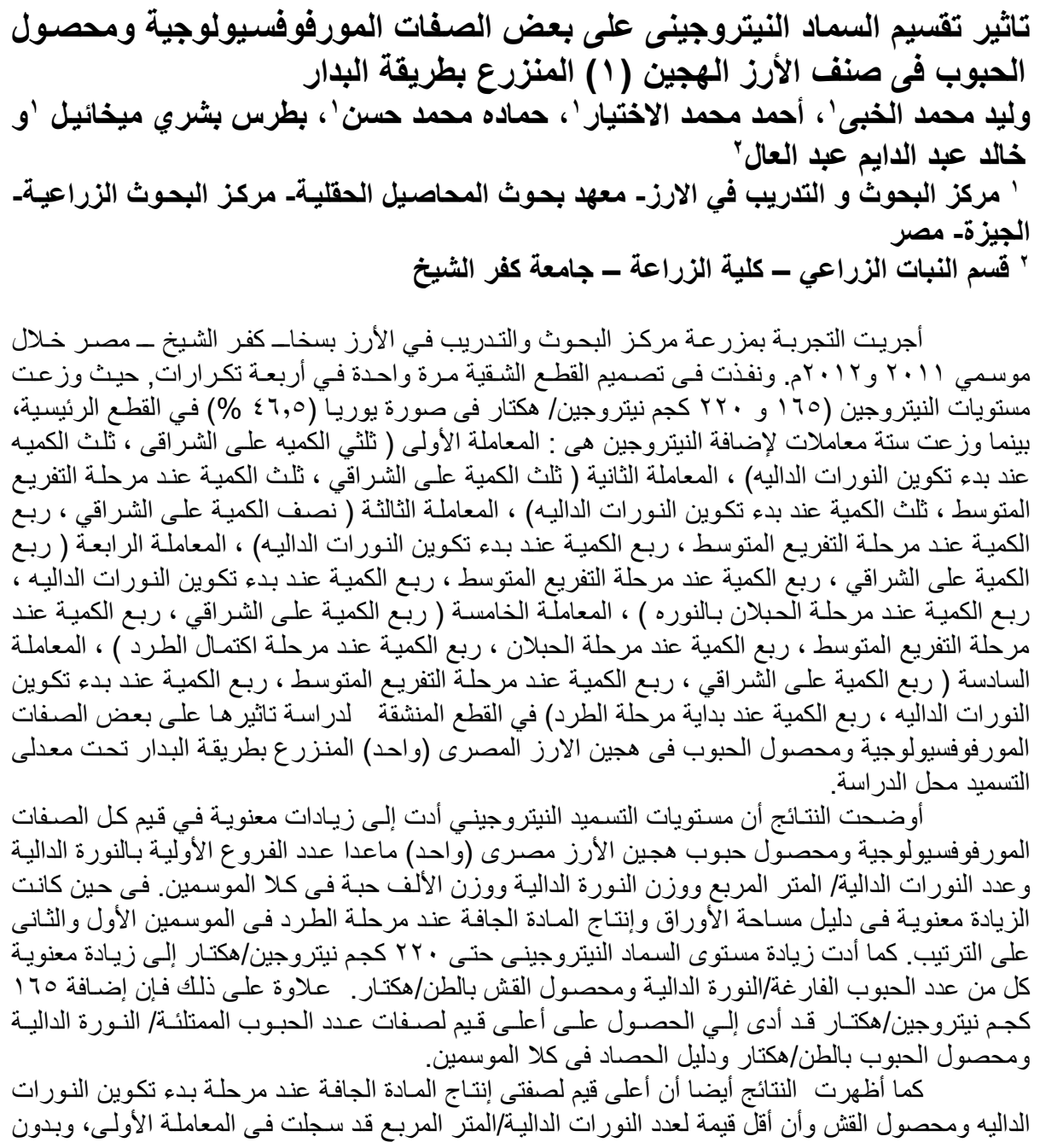




\section{Elkhoby, W. M. et al.}

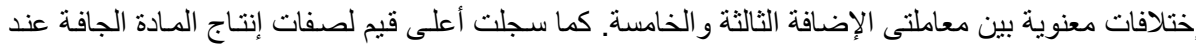

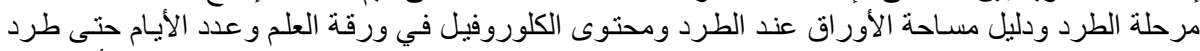

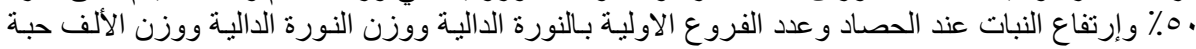

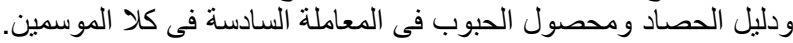

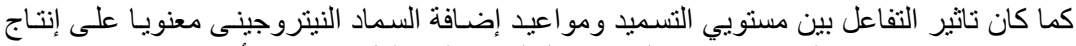

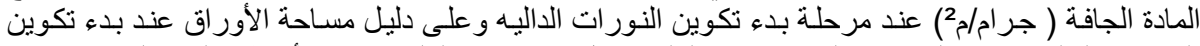

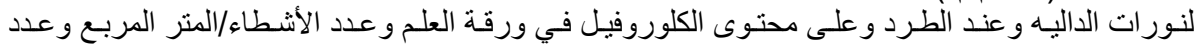

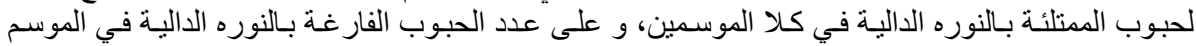

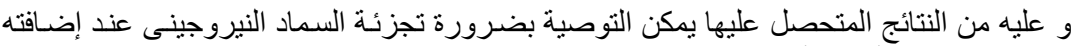
الثاني.

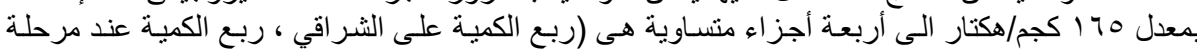

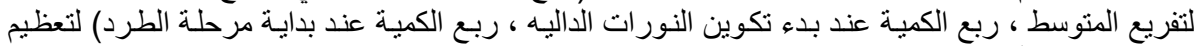
إنتاجية صنف الأرز الهجين ( () الهنزرع بطريقة البدارتحت ظروف الدرات الدراسة.

كلية الزراعة - جامعة المنصورة قام بتحكيم البحث مركز البحوث الزراعيه

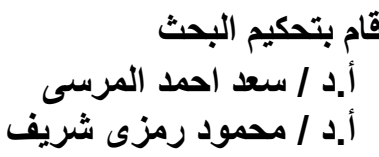

